ISSN 1678-3921

Journal homepage: www.embrapa.br/pab

For manuscript submission and journal contents, access: www.scielo.br/pab

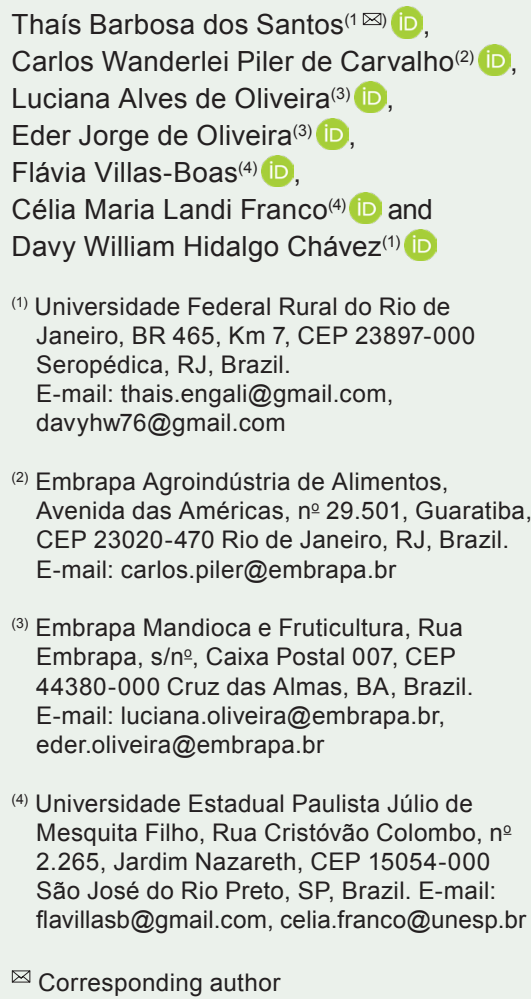

(2) Embrapa Agroindústria de Alimentos, Avenida das Américas, № 29.501, Guaratiba, CEP 23020-470 Rio de Janeiro, RJ, Brazil. E-mail: carlos.piler@embrapa.br

(3) Embrapa Mandioca e Fruticultura, Rua Embrapa, s/no, Caixa Postal 007, CEP 44380-000 Cruz das Almas, BA, Brazil. E-mail: luciana.oliveira@embrapa.br, eder.oliveira@embrapa.br

(4) Universidade Estadual Paulista Júlio de Mesquita Filho, Rua Cristóvão Colombo, № 2.265, Jardim Nazareth, CEP 15054-000 São José do Rio Preto, SP, Brazil. E-mail: flavillasb@gmail.com, celia.franco@unesp.br

$\bowtie$ Corresponding author

Received

January 28, 2021

Accepted

June 08, 2021

How to cite

SANTOS, T.B. dos; CARVALHO, C.W.P. de; OLIVEIRA, L.A. de; OLIVEIRA, E.J. de; VILLAS-BOAS, F.; FRANCO, C.M.L.; CHÁVEZ, D.W.H. Functionality of cassava genotypes for waxy starch. Pesquisa Agropecuária Brasileira, v.56, e02414, 2021 DOI: https://doi.org/10.1590/S1678-3921. pab2021.v56.02414.

\section{Functionality of cassava genotypes for waxy starch}

\begin{abstract}
The objective of this work was to select cassava (Manihot esculenta) genotypes from the Brazilian germplasm bank with a functionality similar to that of waxy starch. A total of 881 genotypes were pre-selected using principal component analysis and hierarchical clustering, and their industrial potential was compared with that of the 7745-5WX waxy cassava and the WX-Maize waxy maize clones, both used as references. Two genotypes stood out: BGM0036 and BGM0083. Samples from these four genotypes were characterized by means of amylose content, scanning electron microscopy, $\mathrm{X}$-ray diffraction, differential scanning calorimetry, paste viscosity, and chainlength distribution of amylopectin. The samples presented A-type crystallinity and no statistical differences $(\mathrm{p}>0.05)$ regarding crystallinity degree (25.3 to 30.0 ), which shows similar proportions of the amylose/amylopectin fractions. No differences were observed in the microstructure of the cassava starches. Initial gelatinization temperature and amylopectin short chains presented a very strong negative correlation, indicating that a lower proportion of short chains of amylopectin results in a higher initial temperature of gelatinization. BGM0036 and BGM0083 show a low final viscosity, close to that of the waxy maize and cassava starches, being an alternative for use in different foods that require stability during freezing.
\end{abstract}

Index terms: Manihot esculenta, amylopectin, paste viscosity, Pearson's correlation, principal component analysis, waxy maize starch.

\section{Funcionalidade de genótipos de mandioca para amido ceroso}

Resumo - O objetivo deste trabalho foi selecionar genótipos de mandioca (Manihot esculenta) do banco de germoplasma brasileiro com funcionalidade semelhante à do amido ceroso. Um total de 881 genótipos foi pré-selecionado por análise de componentes principais e agrupamento hierárquico, e seu potencial industrial foi comparado ao dos clones 7745-5WX de mandioca cerosa e WXMaize de milho ceroso, ambos usados como referência. Dois genótipos se destacaram: BGM0036 e BGM0083. Amostras desses quatro genótipos foram caracterizadas por meio de teor de amilose, microscopia eletrônica de varredura, difração de raios-X, calorimetria diferencial de varredura, viscosidade de pasta e distribuição da cadeia de amilopectina. As amostras apresentaram cristalinidade tipo A e nenhuma diferença estatística $(p>0,05)$ quanto ao grau de cristalinidade (25,3 a 30,0), o que mostra proporções similares das frações de amilose/amilopectina. Não foram observadas diferenças na microestrutura dos amidos de mandioca. A temperatura inicial de gelatinização e as cadeias curtas de amilopectina apresentaram correlação negativa muito forte, o que indica que uma menor proporção de cadeias curtas de amilopectina resulta em uma maior temperatura inicial de gelatinização. BGM0036 e BGM0083 apresentam baixa viscosidade final, próxima às dos amidos de milho e mandioca cerosos, sendo uma alternativa para a utilização em diferentes alimentos que necessitam de estabilidade durante o congelamento. 
Termos para indexação: Manihot esculenta, amilopectina, viscosidade de pasta, correlação de Pearson, análise de componente principal, amido de milho ceroso.

\section{Introduction}

The starch of cassava (Manihot esculenta Crantz), a tropical root crop originated in South America, is easier to extract than that of cereals (Costa et al., 2018; Teixeira et al., 2018). In addition, it is an inexpensive product with desirable pasting properties, which makes it highly demanded in the food industry (Drunkler et al., 2012). However, for the consistent commercial use of this starch, its properties should be investigated considering its functional characteristics.

The functional characteristics of native starches basically depend on physicochemical and structural properties such as size, shape, amylose/amylopectin ratio, chain length of amylopectin, among others (Del Buono et al., 2019). In the food industry, modified or nonmodified starch can be used as a thickener, emulsifier, gel-former, and food texture stabilizer and modifier (Clasen et al., 2018). Other possible applications are in pharmaceuticals, textiles, fuels, biodegradable packaging materials, and thin films of thermoplastics (Shevkani et al., 2017).

Because it is more resistant to freeze and thaw than native starches, there has been a growing interest in natural amylose-free starch (waxy property), which requires reducing chemical waste during the production of some modified starches (Sánchez et al., 2010). In this scenario, an alternative to commercial waxy maize starch is the development of commercial cassava with starch of low or zero amylose (Karlström et al., 2016; Luchese et al., 2017).

Amylose molecules are almost nonexistent in waxy starch, resulting in weak and sticky gels with a lower setback and retrogradation viscosity (Diamantino et al., 2019). Therefore, waxy cassava starch offers advantages for the industry, such as differentiated gel textures with a greater resistance to freezing and thawing than other cereal starches (Sánchez et al., 2010). Consequently, the aim of several research projects has been to develop commercial non-transgenic cassava varieties that produce amylose-free starch (Aiemnaka et al., 2012).
The objective of this work was to select cassava genotypes from the Brazilian germplasm bank with a functionality similar to that of waxy starch.

\section{Materials and Methods}

A total of 881 cassava genotypes from the Brazilian germplasm bank (BGB), maintained by Embrapa Mandioca e Fruticultura in the municipality of Cruz das Almas, in the state of Bahia, Brazil (-12.653 latitude, -39.1219 longitude, 12³9'11"S, 39॰7'19"W, at $212 \mathrm{~m}$ altitude), were cultivated from 2013 to 2016, along with two waxy cassava clones (7734-7WX and 7745-5WX) used as references, which were provided by International Center for Tropical Agriculture (CIAT, Cali, Colombia), totaling 883 different genotypes for pre-selection of a waxy profile.

The principal component analysis (PCA) was applied to the 883 cassava starch genotypes. Of the 881 genotypes, 104 showed the following similar paste viscosity parameters: pasting temperature (PT), peak viscosity at $95^{\circ} \mathrm{C}(\mathrm{PV})$, minimum viscosity after heating $(\mathrm{mV})$, breakdown viscosity $(\mathrm{BD})(\mathrm{PV}-\mathrm{mV})$, maximum viscosity during cooling (MVC), setback viscosity (SB) (FV-mV), final viscosity (FV), and cold viscosity peak at $50^{\circ} \mathrm{C}(\mathrm{CV})$. These readings were compared with those of the 7734-7WX and 7745-5WX waxy clones, totaling 106 genotypes, which were evaluated using the Series 4 Rapid Visco Analyser (RVA) (Newport Scientific Pty Ltd., Warriewood, Australia).

The 104 genotypes from the BGB plus the 2 genotypes from CIAT were cultivated again in the 2016/2017 crop season, in an experimental field of Embrapa. This time, only 47 cassava genotypes were pre-selected for having a viscosity profile close to that of the waxy starch used for starch extraction: 45 from the BGB (BGM0036, BGM0037, BGM0080, BGM0083, BGM0087, BGM0120, BGM0288, BGM0364, BGM0368, BGM0380, BGM0489, BGM0557, BGM0561, BGM0575, BGM0591, BGM0914, BGM0934, BGM0962, BGM0975, BGM0995, BGM0996, BGM1044, BGM1103, BGM1134, BGM1142, BGM1158, BGM1265, BGM1291, BGM1335, BGM1358, BGM1415, BGM1448, BGM1503, BGM1518, BGM1637, BGM1643, BGM1660, BGM1684, BGM1692, BGM1733, BGM1734, BGM1742, BGM1769, 
BGM1818, and BGM1884) and 2 from CIAT (77347WX and 7745-5WX).

Cassava fresh roots of the 45 genotypes from the BGB and the 2 genotypes from CIAT were washed, peeled, manually cut into small pieces, and placed in a $2 \mathrm{~L}$ blender with non-sharp edge blades for $1 \mathrm{~min}$ at a ratio of 1:1 root:water. Subsequently, the material was filtered through a 150 mesh $(0.105 \mathrm{~mm})$ cloth in excess of water; the mixture was left for $30 \mathrm{~min}$ to allow starch decantation and then dried in a fan oven at $40^{\circ} \mathrm{C}$ until a final moisture content of $8 \pm 2 \%$. No chemicals were added during this process, as darkening was not observed.

After starch was extracted from the 47 pre-selected genotypes, another PCA was carried out using the data obtained with the RVA; for this, a commercial waxy starch (named in this work as WX-Maize), donated by Ingredion (Mogi das Cruzes, SP, Brazil), was used as a control, totaling 48 samples. The data were analyzed using the Thermocline software for Windows (Newport Scientific Pty Ltd, Warriewood, Australia), profile Standard 1 of the RVA manual (Newport Scientific Pty Ltd., Warriewood, Australia), and Table III of method 76-21.01 of American Association of Cereal Chemists (AACC, 1999).

After the application of PCA and hierarchical clustering of principal components, two cassava genotypes were selected - BGM0036 and BMG0083 -, which presented a similar RVA profile, i.e., similar PT, PV, mV, BD, MVC, SB, FV, and CV. Based on this result, genotypes BGM0036, BGM0083, 7745-5WX, and WX-Maize were chosen to be further analyzed by means of amylose content, scanning electron microscopy, X-ray diffraction, differential scanning calorimetry, paste viscosity, and chain-length distribution of amylopectin.

The amylose content of the studied genotypes (100 mg) was analyzed using standardized iodine colorimetry in triplicate, following method 6647-22015 of International Standardization Organization (ISO, 2015). To assess the absorbance of the cassava starches, an iodine mixture was obtained at $620 \mathrm{~nm}$ using the same methodology.

Samples at $7 \pm 1 \%$ moisture content were placed in the X-ray diffraction D2 Phaser (Bruker, Rheinfelden, Germany) in order to determine the crystalline region under the main peaks from 2 to $32^{\circ}$ (angle 2theta), following the methodology of Bernardo et al. (2018).
The relative crystallinity value was obtained using the Diffrac.Eva, version 3.2, software (Bruker AXS, Rheinfelden, Germany).

Starch thermal properties were evaluated with the Q200 Differential Scanning Calorimeter (TA Instruments, New Castle, DE, USA). The degree of gelatinization was measured with the Universal Analysis 2000, version 4.5A, software(TA Instruments, New Castle, DE, USA). The heating curve profile was used to calculate onset (To), peak (Tp), conclusion (Tc), and calorimetric enthalpy $(\Delta \mathrm{H})$ temperatures, as well as gelatinization temperature range $(\Delta \mathrm{T})$, as described in Bernardo et al. (2018) and Wasserman et al. (2019).

The branch chain of amylopectin was determined using high performance anionexchange chromatography with the ICS 3000 pulsed amperometric detection (HPAEC-PAD) system (Dionex Corporation, Sunnyvale, CA, USA). The starches were classified within the following ranges of degree of polymerization (DP): 6-12, 13-24, 25-36, and $\geq 37$; 6-12 represents short chains and $\geq 37$ long branch chains according to Costa et al. (2018). The used samples were prepared with the methodology of Wong \& Jane (1995).

Starch morphology was analyzed in the TM 3000 low-vacuum benchtop scanning electron microscope (Hitachi, Tokyo, Japan) at an accelerating voltage of $15 \mathrm{kV}$ (Bernardo et al., 2018).

The analysis of variance and Tukey's test for mean comparison at $5 \%$ probability were carried out. PCA and hierarchical clustering on principal components (HCPC) were also applied to confirm the groups suggested by PCA, and both tools were used to complement each other (Ferreira et al., 2017). PCA was performed on RVA data readings (variables) and also after variable standardization to avoid the influence of different magnitude orders. HCPC used Euclidean distances and Ward's method as aggregation criteria. To determine the number of groups, the NbClust function (Charrad et al., 2014) tested 30 different statistical methods to calculate the optimal number of clusters. Pearson's correlation was used to analyze the interactions among variables. All statistical analyses were conducted using the $R$, version 3.2.4, software (R Core Team, 2016). 


\section{Results and Discussion}

The PCA of the RVA parameters resulted in vectors PT, PV, mV, BD, MVC, SB, FV, and CV of the 883 cassava genotypes pre-selected for starches with a waxy profile (Figure $1 \mathrm{~A}$ ). The two first principal component analyses explained $71.3 \%$ of total variability (51.4 plus $19.9 \%$ ) (Figure $1 \mathrm{~A}$ and B), which is acceptable according to Everitt et al. (2005). With the application of the PCA, the 883 genotypes were distributed into six groups, based on the similarities among their RVA profiles (Figure $1 \mathrm{~B}$ and Table 1).

Group 1 stood out for containing the 7734-7WX and $7745-5 \mathrm{WX}$ reference waxy genotypes. This was the group of interest of this study because its 106 genotypes showed a paste property profile similar to that of the waxy starches (Table 1). The remaining 777 genotypes were not evaluated because they did not have the sought waxy profile.

According to the rules for measuring the strength of Pearson's correlation coefficient mentioned by Teles et al. (2019), there is a positive and very strong correlation between FV and MVC ( $\mathrm{r}=0.996)$, and positive and strong correlations between $\mathrm{FV}$ and $\mathrm{mV}(\mathrm{r}=0.830)$, MVC and $\mathrm{mV}(\mathrm{r}=0.836)$, and BD and PV $(\mathrm{r}=0.825)$ (Figure $1 \mathrm{C}$ ). FV corresponds to starch paste capacity during cooling and is directly associated with starch gel hardness also during cooling (Shang et al., 2016). Additionally, for the analyzed samples, FV was highly associated with MVC and $\mathrm{mV}$.

The PCA of the 48 genotypes pre-selected for the waxy profile of their starches (45 from the BGB, 2 from CIAT, and the WX-Maize commercial maize) resulted in new vectors of the RVA parameters - PT, $\mathrm{PV}, \mathrm{mV}, \mathrm{BD}, \mathrm{MVC}, \mathrm{SB}, \mathrm{FV}$, and $\mathrm{CV}$ (Figure $1 \mathrm{D}$ ). These 48 starches were distributed according to their viscosity profile (Figure $1 \mathrm{E}$ ): cassava starches with low $\mathrm{mV}, \mathrm{MVC}$, and FV values are located at the left side of the PCA, closer to the waxy references. This means that these cassava starches showed a greater similarity to the waxy profile, also presenting paste readings similar to that of WX-Maize. The carried out PCAs (Figure $1 \mathrm{D}$ and E) explained $77.0 \%$ of total variability (55.7 plus 21.3\%).

Pearson's correlation coefficient for the 45 selected cassava starches, 7734-7WX, 7745-5WX, and WXMaize showed a positive and very strong correlation between FV and MVC ( $\mathrm{r}=0.998), \mathrm{FV}$ and $\mathrm{mV}$ $(r=0.844)$, MVC and $\mathrm{mV}(\mathrm{r}=0.857)$, and $\mathrm{BD}$ and PV $(\mathrm{r}=0.935)$ (Figure $1 \mathrm{~F})$. The same correlation was observed in the first correlogram, but with higher $r$ values, indicating a greater proximity to the reference starches (Figure 1 F). HCPC confirmed the similarities among the samples and, by using NbClust, three groups were formed (Figure $1 \mathrm{G}$ ).

The paste profiles of genotypes BGM0036 and BGM0083, selected because of their waxy starch functionality, were very similar to each other and similar to the peak viscosity value of WX-Maize (Figure 2 A). Although the profile of WX-Maize was slightly different from that of the two cassava starches, the final viscosity of all three was also quite similar. Genotype 7745-5WX showed a considerably lower FV $(\sim 1,900 \mathrm{cP})$ than that of the other three samples. The shape of the paste profile of $7745-5 \mathrm{WX}$ was different from that of BGM0036, BGM0083 and WXMaize, which was intriguing since the paste curve was consistent with the replicate.

In addition, the WX-Maize starch pastes were similar to those obtained from BGM0036 and BGM0083, also presenting a low tendency to retrograde.

Amylose content did not differ significatly between the straches from BGM0036 (23.90 \pm 0.16$)$ and BGM0083 (23.88 \pm 0.36 ), which, however, differed from the starches from the 7745-5WX reference genotype $(0.72 \pm 0.09)$ and the commercial waxy maize with an amylopectin content of almost $99 \%$ (approximately 1.0\% amylose) (Velásquez-Castillo et al., 2020). Although the amylose content of the cassava starches presented a statistical approximation in PCA, the same correlation was not true for the reference waxy samples.

The X-ray diffraction profiles of the three cassava starches were similar to that of WX-Maize, showing an A-type crystalline pattern (Figure 2 B). Peaks were found at $15,17,18$, and $23^{\circ}$ ( $2 \theta$ angle), which is in agreement with the results of Wang et al. (2018), who analyzed starches and concluded that maize starch presented a crystalinity similar to that of cassava starches.

In the present study, in general, cassava starches showed a crystalinity similar to that of WX-Maize ( $>0.05$ ). For BGM083 and WX-Maize, for example, crystallinity varied from 25.3 to $30.0 \%$ (Figure 2 B). Hsieh et al. (2019) found that the crystallinity of waxy and normal cassava starches was similar to that of cereal starches, such as waxy wheat and rice, but slightly different from that of waxy potato and maize starches. 
The results obtained for the studied thermal properties showed that BGM0036 presented the lowest To of $62.34^{\circ} \mathrm{C}$ and the highest $\Delta \mathrm{T}$ and $\Delta \mathrm{H}$ of $27.1^{\circ} \mathrm{C}$ and $14.82 \mathrm{~J} \mathrm{~g}^{-1}$, respectively (Table 2). According to Schmitz et al. (2017), the large heterogeneity of starch granules is linked to low gelatinization temperatures
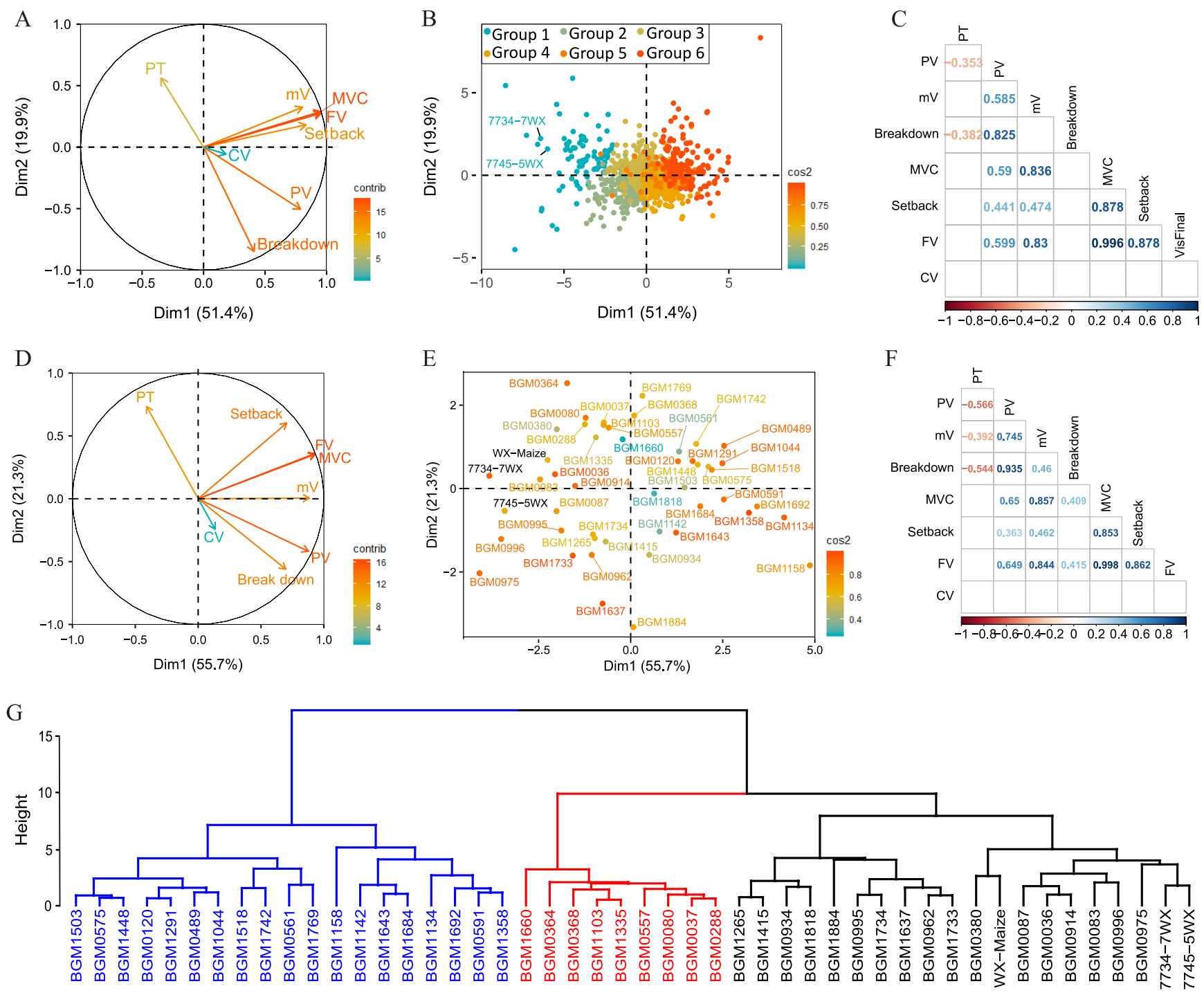

Figure 1. Principal component analysis (PCA) of 883 cassava (Manihot esculenta) genotypes - 881 from the Brazilian germplasm bank (BGB) and 2 (7734-7WX and 7745-5WX) from International Center for Tropical Agriculture -, specifically for: A, the parameters evaluated by the Rapid Visco Analyser (RVA), i.e., pasting temperature (PT), peak viscosity at $95^{\circ} \mathrm{C}$ (PV), minimum viscosity after heating $(\mathrm{mV})$, breakdown viscosity (PV-mV), maximum viscosity during cooling (MVC), setback viscosity $(\mathrm{FV}-\mathrm{mV})$, final viscosity (FV), and cold viscosity peak at $50^{\circ} \mathrm{C}(\mathrm{CV})$, resulting in vectors of all the 833 genotypes for the pre-selection of starches with a waxy profile; $\mathrm{B}$, distribution, according to viscosity profile, of the starches of the 833 genotypes into groups, among which group 1 stands out for containing the 7734-7WX and 7745-5WX reference waxy genotypes; C, correlogram for the RVA parameters of all genotypes, presenting only significant correlations $(\mathrm{p}<$ 0.05); D, RVA parameters, resulting in vectors of 48 genotypes pre-selected for the waxy profile of their starches, i.e., 45 from the BGB, 7734-7WX, 7745-5WX, and WX-Maize; E, 48 pre-selected starches for waxy profile, distributed according to viscosity profile; F, correlogram for the RVA parameters from the 48 pre-selected starches, presenting only significant correlations ( $\mathrm{p}<0.05)$; and $\mathrm{G}$, hierarchical clustering of the 48 pre-selected starches for waxy profile using NbClust, resulting in a division into three groups, confirming the similarities of the genotypes through PCA. 
and that the high granule percentage is directly related to a high gelatinization range and enthalpy.

In the same way, 7745-5WX, WX-Maize, and BGM0083 showed a similar relationship by presenting a lower $\Delta \mathrm{T}$ of $13.28,15.26$, and $21.30^{\circ} \mathrm{C}$ and a lower $\Delta \mathrm{H}$ of $12.12,12.20$, and $12.65 \mathrm{~J} \mathrm{~g}^{-1}$ (Table 2), respectively, indicating a decrease in the energy required to melt the amylopectin crystals that contribute to the swelling of the granules (Schmitz et al., 2017).

Hsieh et al. (2019) found that the $\Delta H$ of waxy cassava starch was $18.5 \mathrm{~J} \mathrm{~g}^{-1}$, while that of waxy maize starches ranged between 13.6 and $18.9 \mathrm{~J} \mathrm{~g}^{-1}$, indicating that this paramener varies considerably. Srichuwong et al. (2005) reported a $\Delta \mathrm{H}$ of $17.6 \mathrm{~J} \mathrm{~g}^{-1}$ for normal cassava starch.

Cassava and maize starches showed bimodal distributions of DP, with a first peak at a DP of 11 for BGM0036 and BGM0083 and of 12 for $7745-5 \mathrm{WX}$ and WX-Maize, and a second peak at a DP of 45 for BGM0036 and 7745-5WX, 46 for BGM0083, and 42 for WX-Maize (Figure $2 \mathrm{C}$ ).

The highest DP value of 91 was obtained for 7745$5 \mathrm{WX}$, followed by that of 90 for BGM0036 and BGM0083, and of 89 for WX-Maize (Table 2). The first three genotypes also showed a higher proportion of long chains (DP $\geq 37$ ) when compared with WXMaize. Similar results were reported by Jane et al.
(1999), who found a higher proportion of long chains for varied botanical sources of starches in comparison with WX-Maize.

All cassava starches presented a higher amount of short chains (DP from 6-12), ranging from 24.95 to $25.53 \%$, when compared with WX-Maize, with a value of $22.96 \%$. The proportion of long chains ( $\mathrm{DP} \geq 37$ ) ranged from 16.29 to $17.19 \%$ for cassava starches and was of $14.60 \%$ for WX-Maize (Table 2).

Srichuwong et al. (2005) observed a higher proportion of amylopectin short unit chain-length in A-type crystals. Starches with short chains of amylopectin are usually used in the frozen food industry, as they enable an excellent water retention capacity with minor retrogradation and syneresis during refrigeration or defrosting (Schmitz et al., 2017).

Cassava starch showed a DP ranging from 1921 (Figure $2 \mathrm{C}$ ), causing a defect in its crystalline structure, which results in a shoulder of greater or lesser intensity in the distribution of amylopectin side chains. WX-Maize, however, did not have a shoulder in its structure, as also observed by Jane et al. (1999).

All cassava starches presented round and truncated-shaped granules of smooth surface and with an indentation, particularly on one side (Figure 3). However, WX-Maize starch presented a

Table 1. Classification by the principal component analysis of 883 cassava (Manihot esculenta) genotypes (881 from the Brazilian germplasm bank and two - 7734-7WX and 7745-5WX - from International Center for Tropical Agriculture) into six groups according to similarity of pasting properties ${ }^{(1)}$.

\begin{tabular}{lcccccccc}
\hline Group & $\mathrm{PT}\left({ }^{\circ} \mathrm{C}\right)$ & $\mathrm{PV}(\mathrm{cP})$ & $\mathrm{mV}(\mathrm{cP})$ & $\mathrm{BD}(\mathrm{cP})$ & $\mathrm{MVC}(\mathrm{cP})$ & $\mathrm{SB}(\mathrm{cP})$ & $\mathrm{FV}(\mathrm{cP})$ & $\mathrm{CV}(\mathrm{cP})$ \\
\hline $1^{(2)}$ & $71.0 \pm 1.5 \mathrm{a}$ & $4169.7 \pm 422.2 \mathrm{e}$ & $1545.3 \pm 189.3 \mathrm{~d}$ & $2624.4 \pm 320.6 \mathrm{e}$ & $2412.6 \pm 313.5 \mathrm{~d}$ & $866.8 \pm 187.9 \mathrm{c}$ & $2395.4 \pm 307.1 \mathrm{e}$ & $29.5 \pm 24.7 \mathrm{a}$ \\
2 & $69.7 \pm 1.8 \mathrm{~b}$ & $4494.1 \pm 329.5 \mathrm{~d}$ & $1158.2 \pm 215.2 \mathrm{e}$ & $3335.9 \pm 377.1 \mathrm{~b}$ & $1677.3 \pm 337.2 \mathrm{e}$ & $517.8 \pm 142.9 \mathrm{~d}$ & $1669.2 \pm 334.6 \mathrm{f}$ & $37.0 \pm 35.1 \mathrm{a}$ \\
3 & $70.7 \pm 1.4 \mathrm{a}$ & $4788.0 \pm 259.9 \mathrm{c}$ & $1801.4 \pm 147.0 \mathrm{~b}$ & $2986.6 \pm 213.8 \mathrm{~d}$ & $3013.5 \pm 190.3 \mathrm{~b}$ & $1210.4 \pm 150.4 \mathrm{~b}$ & $2967.4 \pm 176.2 \mathrm{c}$ & $36.2 \pm 28.6 \mathrm{a}$ \\
4 & $69.4 \pm 1.3 \mathrm{~b}$ & $4818.1 \pm 269.4 \mathrm{c}$ & $1670.1 \pm 156.6 \mathrm{c}$ & $3148.1 \pm 227.3 \mathrm{c}$ & $2597.3 \pm 206.7 \mathrm{c}$ & $925.3 \pm 147.8 \mathrm{c}$ & $2575.9 \pm 203.1 \mathrm{~d}$ & $33.3 \pm 27.1 \mathrm{a}$ \\
5 & $69.3 \pm 1.3 \mathrm{~b}$ & $5219.9 \pm 346.5 \mathrm{~b}$ & $2059.9 \pm 211.8 \mathrm{a}$ & $3160.0 \pm 267.3 \mathrm{c}$ & $3450.2 \pm 279.4 \mathrm{a}$ & $1390.3 \pm 192.4 \mathrm{a}$ & $3345.4 \pm 258.0 \mathrm{a}$ & $37.3 \pm 30.4 \mathrm{a}$ \\
6 & $68.5 \pm 1.7 \mathrm{c}$ & $5353.6 \pm 487.4 \mathrm{a}$ & $1721.7 \pm 218.2 \mathrm{c}$ & $3631.8 \pm 399.6 \mathrm{a}$ & $3082.3 \pm 249.4 \mathrm{~b}$ & $1351.2 \pm 284.4 \mathrm{a}$ & $3040.5 \pm 241.8 \mathrm{~b}$ & $27.0 \pm 30.1 \mathrm{a}$ \\
\hline
\end{tabular}

${ }^{(1)}$ Values followed by equal letters, in the same column, do not differ by Tukey's, at 5\% probability. The following pasting properties were read using the curve of the Series 4 Rapid Visco Analyser: PT, pasting temperature; PV, peak viscosity at $95^{\circ} \mathrm{C} ; \mathrm{mV}$, minimum viscosity after heating; $\mathrm{BD}$, breakdown viscosity (PV-mV); MVC, maximum viscosity during cooling; SB, setback viscosity (FV-mV); FV, final viscosity; and CV, cold viscosity peak at $50^{\circ} \mathrm{C} .{ }^{(2)}$ Group of interest of the study, due to the waxy profile of its genotypes: 7734-7 WX, 7745-5WX, BGM0036, BGM0037, BGM0049, BGM0080, BGM0081, BGM0082, BGM0083, BGM0087, BGM0093, BGM0120, BGM0128, BGM0141, BGM0160, BGM0193, BGM0214, BGM0218, BGM0223, BGM0230, BGM0274, BGM0288, BGM0310, BGM0327, BGM0334, BGM0355, BGM0364, BGM0368, BGM0370, BGM0380, BGM0403, BGM0427, BGM0434, BGM0452, BGM0489, BGM0492, BGM0496, BGM0557, BGM0561, BGM0575, BGM0591, BGM0602, BGM0610, BGM0630, BGM0687, BGM0689, BGM0729, BGM0905, BGM0914, BGM0934, BGM0936, BGM0951, BGM0955, BGM0956, BGM0962, BGM0972, BGM0975, BGM0981, BGM0995, BGM0996, BGM1044, BGM1077, BGM1088, BGM1103, BGM1134, BGM1135, BGM1142, BGM1143, BGM1148, BGM1158, BGM1160, BGM1186, BGM1209, BGM1218, BGM1265, BGM1291, BGM1303, BGM1335, BGM1358, BGM1382, BGM1407, BGM1415, BGM1448, BGM1473, BGM1503, BGM1515, BGM1516, BGM1518, BGM1547, BGM1607, BGM1611, BGM1637, BGM1643, BGM1660, BGM1684, BGM1692, BGM1733, BGM1734, BGM1742, BGM1750, BGM1769, BGM1818, BGM1884, BRS Caipira, BRS Kiriris, and BRS Verdinha. 
typical polyhedral shape, with an indentation and the presence of small cavities on its surface. Hsieh et al. (2019) reported the same shape characteristics for waxy and normal cassava starches and waxy maize starches.

In Pearson's correlation, crystallinity presented a very strong positive correlation of 0.99 with $\mathrm{mV}$ (Table 3). Moreover, enthalpy and Tp also had a very strong positive correlation of 0.97 , which is associated with the disruption of the amylopectin crystal during gelatinization.

Regarding DP, there was a negative correlation of -0.98 between the ranges of $6-12$ and of $25-36$, whereas that of 13-24 presented a positive correlation of $0.98,0.97$, and 0.98 with those of $6-12,25-36$, and $\geq 37$, respectively (Table 3 ).
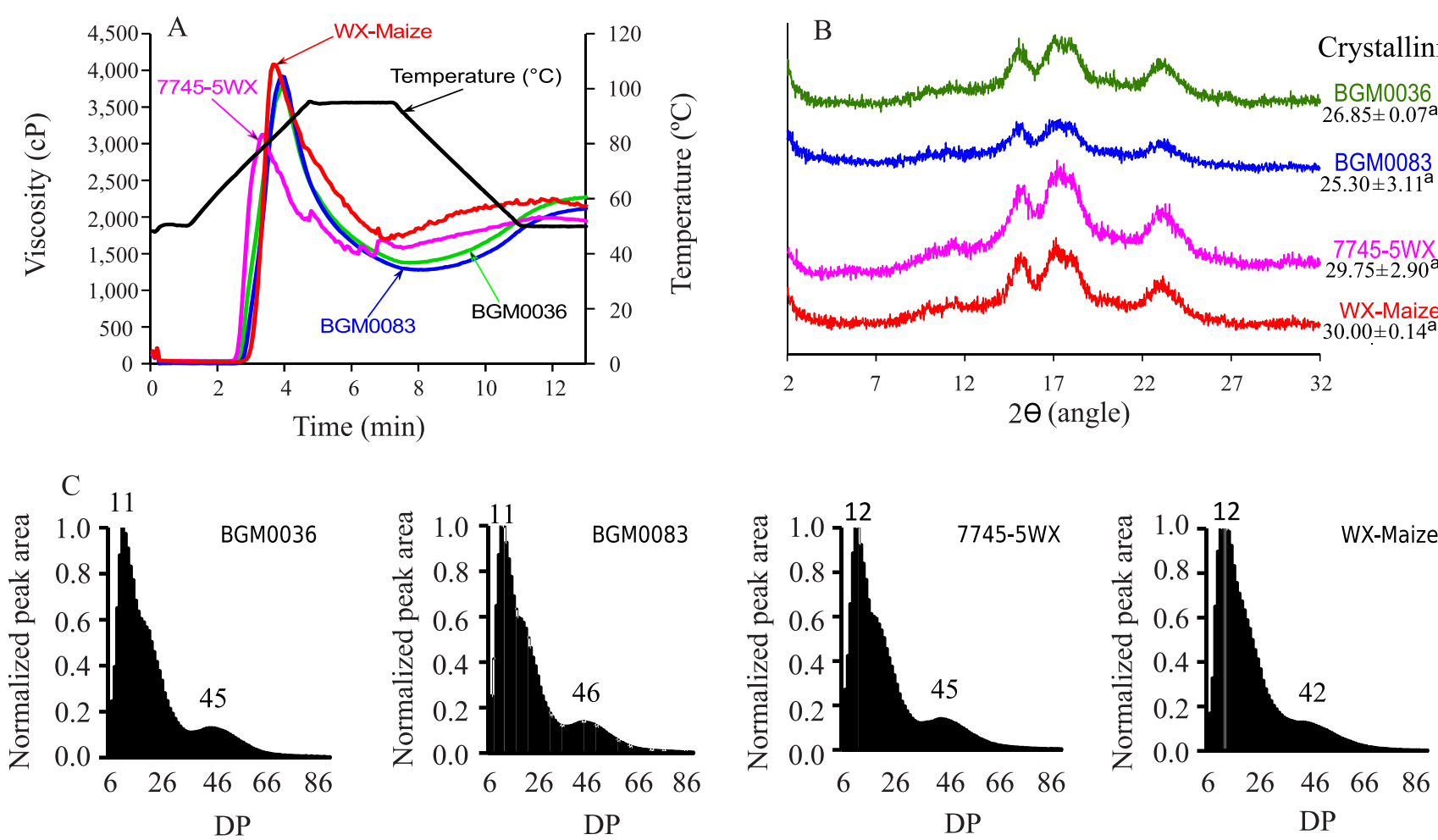

Figure 2. Physicochemical analysis of the BGM0036 and BGM0083 cassava (Manihot esculenta) genotypes, obtained from the Brazilian germplasm bank, with a waxy starch functionality similar to that of the starches of the 7745-5WX waxy cassava clone from International Center for Tropical Agriculture and the WX-Maize commercial waxy maize (Zea mays) clone, both used as references, showing: A, paste viscosity profile obtained by the Rapid Visco Analyser (RVA); B, X-ray diffraction patterns to determine the crystalline region under the main peaks from 2 to $32^{\circ}$ (angle 2theta) and the relative crystallinity value obtained with the Diffrac.Eva software - values followed by equal letters for each starch do not differ by Tukey's test, at $5 \%$ probability; and C, normalized amylopectin branch chain-length distributions, determined by high performance anion-exchange chromatography with a pulsed amperometric detection system. The starches are classified by degree of polymerization (DP).

Pesq. agropec. bras., Brasília, v.56, e02414, 2021 DOI: 10.1590/S1678-3921.pab2021.v56.02414 
Table 2. Thermal properties, branch chain-length distribution of amylopectins, and amylose content of starches of cassava (Manihot esculenta) genotypes selected for showing a waxy starch functionality similar to that of the starches of the 77455 WX waxy cassava and the WX-Maize commercial waxy maize (Zea mays) clones ${ }^{(1)}$.

\begin{tabular}{|c|c|c|c|c|c|c|c|c|c|c|c|}
\hline \multirow[t]{2}{*}{ Genotype $^{(2)}$} & \multicolumn{5}{|c|}{ Thermal property ${ }^{(3)}$} & \multicolumn{5}{|c|}{ Branch chain-length distribution (\%) } & \multirow{2}{*}{$\begin{array}{c}\text { Amylose } \\
\text { content } \\
(\%)\end{array}$} \\
\hline & $\begin{array}{l}\text { To } \\
\left({ }^{\circ} \mathrm{C}\right)\end{array}$ & $\begin{array}{l}\mathrm{Tp} \\
\left({ }^{\circ} \mathrm{C}\right)\end{array}$ & $\begin{array}{c}\mathrm{Tc} \\
\left({ }^{\circ} \mathrm{C}\right)\end{array}$ & $\begin{array}{c}\Delta \mathrm{H} \\
\left(\mathrm{J} \mathrm{g}^{-1}\right)\end{array}$ & $\begin{array}{c}\Delta \mathrm{T} \\
\left({ }^{\circ} \mathrm{C}\right)\end{array}$ & $\begin{array}{c}\text { DP from } \\
6-12\end{array}$ & $\begin{array}{c}\text { DP from } \\
13-24\end{array}$ & $\begin{array}{c}\text { DP from } \\
25-36\end{array}$ & $\mathrm{DP} \geq 37$ & $\begin{array}{l}\text { Highest de- } \\
\text { tected DP }\end{array}$ & \\
\hline BGM0036 & 62.34 & 69.94 & 89.44 & 14.82 & 27.10 & $25.28 \pm 0.25 \mathrm{ab}$ & $44.11 \pm 0.28 \mathrm{~b}$ & $14.34 \pm 0.15 b$ & $16.29 \pm 0.38 b$ & 90 & $23.90 \pm 0.16 \mathrm{a}$ \\
\hline BGM0083 & 63.36 & 74.58 & 84.66 & 12.65 & 21.30 & $24.95 \pm 0.04 \mathrm{~b}$ & $43.40 \pm 0.02 b c$ & $14.47 \pm 0.01 \mathrm{~b}$ & $17.19 \pm 0.01 \mathrm{a}$ & 90 & $23.88 \pm 0.36 \mathrm{a}$ \\
\hline 7745-5WX & 67.97 & 72.94 & 81.25 & 12.12 & 13.28 & $25.53 \pm 0.08 \mathrm{a}$ & $42.908 \pm 0.16 \mathrm{c}$ & $14.45 \pm 0.05 b$ & $17.05 \pm 0.02 \mathrm{ab}$ & 91 & $0.72 \pm 0.09 \mathrm{~b}$ \\
\hline WX-Maize & 68.25 & 74.12 & 83.51 & 12.20 & 15.26 & $22.96 \pm 0.01 \mathrm{c}$ & $46.807 \pm 0.25 \mathrm{a}$ & $15.57 \pm 0.05 \mathrm{a}$ & $14.60 \pm 0.19 \mathrm{c}$ & 89 & NQ \\
\hline
\end{tabular}

${ }^{(1)}$ Values followed by equal letters, in the same column for each starch, do not differ by Tukey's test, at $5 \%$ probability. ${ }^{(2)}$ BGM0036 and BGM0083 are cassava genotypes from the Brazilian germplasm bank. ${ }^{(3)}$ Temperatures of gelatinization: To, onset; Tp, peak; Tc, conclusion; $\Delta \mathrm{H}$, calorimetric enthalpy; and $\Delta \mathrm{T}$, gelatinization temperature range. DP, degree of polymerization. NQ, values not quantified.

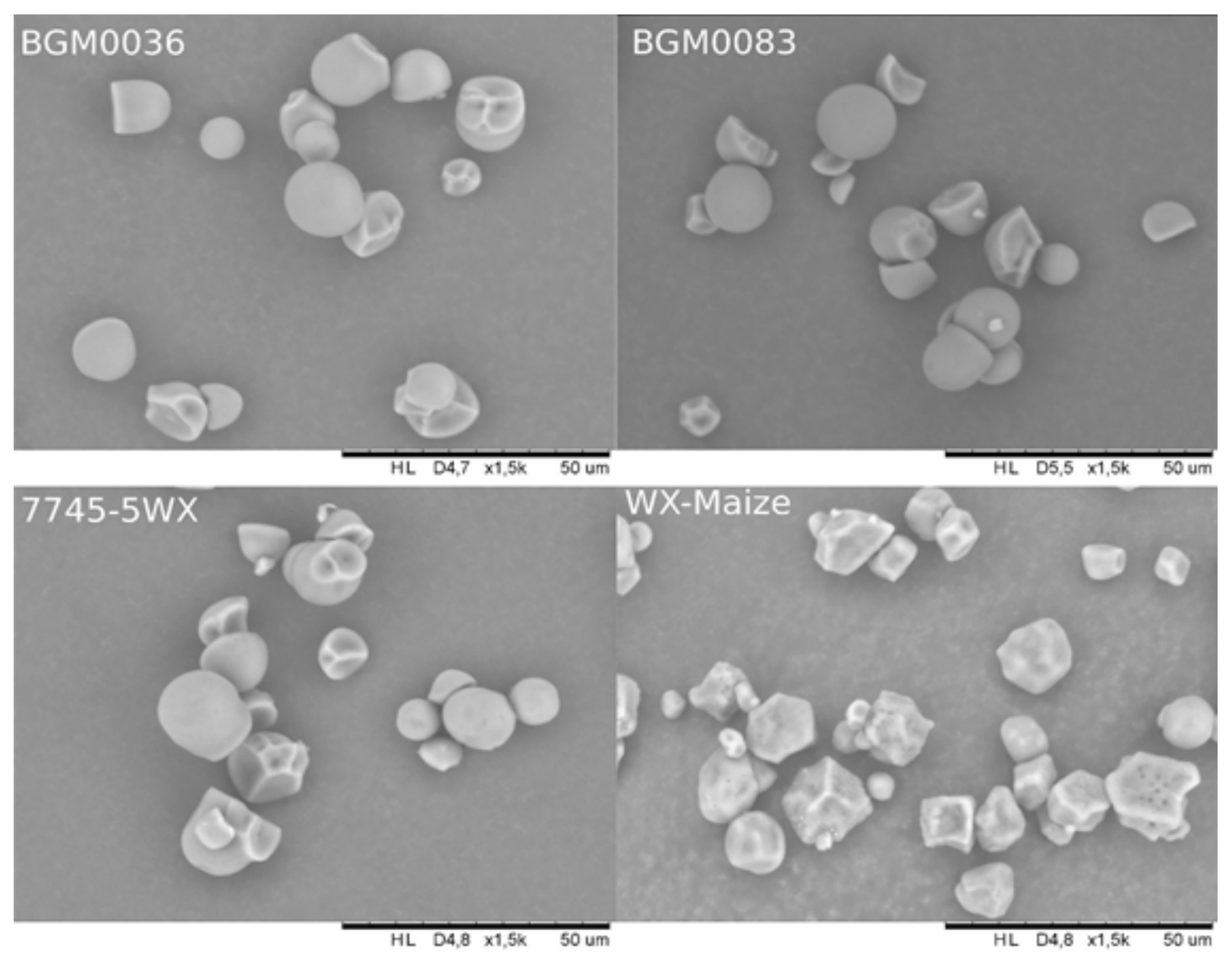

Figure 3. Scanning electron micrographs, comparing sizes and morphology of the starch granules of the BGM0036 and BGM0083 cassava (Manihot esculenta) genotypes, obtained from the Brazilian germplasm bank, with a waxy starch functionality similar to that of the starches of the 7745-5WX waxy cassava clone from International Center for Tropical Agriculture and the WX-Maize commercial waxy maize (Zea mays) clone, both used as references. All micrographs are presented at a magnification of $1,500 \mathrm{X}$. 
Table 3. Pearson's correlation between the physical and chemical properties of starches from cassava (Manihot esculenta) genotypes from the Brazilian germplasm bank (BGM0036 and BGM0083) and from the 7745-5WX waxy cassava and the WX-Maize commercial waxy maize (Zea mays) clones.

\begin{tabular}{lc}
\hline Variable $^{(1)}$ & Statistical correlation $^{(2)}$ \\
\hline Crystallinity and $\mathrm{mV}$ & 0.99 \\
$\Delta \mathrm{H}$ and Tp & 0.97 \\
DP from 6-12 and DP from 25-36 & -0.98 \\
DP from 13-24 and DP from 6-12 & 0.98 \\
DP from 13-24 and DP from 25-36 & 0.97 \\
DP from 13-24 and DP $\geq 37$ & 0.98 \\
To and DP from 6-12 & -1.00 \\
To and DP from 13-24 & 0.97 \\
To and DP from 25-36 & 0.98 \\
PT and highest DP & 0.99
\end{tabular}

${ }^{(1)} \mathrm{mV}$, miminum viscosity; $\Delta \mathrm{H}$, calorimetric enthalpy; Tp, gelatinization temperature; DP, degree of polymerization; To, onset temperature; and PT, pasting temperature. ${ }^{(2)}$ In statistical correlation, negative values show an inversely proportional correlation, and positive values show a directly proportional correlation.

Short chain fractions (DP from 6-11) were negatively correlated with To. Furthermore, side chains with a high proportion of DP from 6-9 decreased pasting onset temperature, but chain length had no significant effect on PV, BD, SB, and FV (Park et al., 2007).

\section{Conclusion}

The starches of the BGM0036 and BGM0083 cassava (Manihot esculenta) genotypes from the Brazilian germplasm bank show a paste viscosity reading close to that of the starches of the 7745-5WX waxy cassava and WX-Maize waxy maize (Zea mays) clones, which is an indicative of their potential both in the industry due to this specific viscosity characteristic and as an alternative for use in different foods requiring stability during freezing.

\section{Acknowledgement}

To Empresa Brasileira de Pesquisa Agropecuária (Embrapa), for support (project number 20.18.01.012.00.00).

\section{References}

AACC. American Association of Cereal Chemists. AACC approved methods of analysis. $11^{\text {th }}$ ed. St. Paul: Cereals \& Grains Association, 1999. Method 76-21.01: General pasting method for wheat or rye flour or starch using the rapid visco analyser.

AIEMNAKA, P.; WONGKAEW, A.; CHANTHAWORN, J.; NAGASHIMA, S.K.; BOONMA, S.; AUTHAPUN, J.; JENWEERAWAT, S.; KONGSILA, P.; KITTIPADAKUL, P.; NAKASATHIEN, S.; SREEWONGCHAI, T.; WANNARAT, W.; VICHUKIT, V.; LÓPEZ-LAVALLE, L.A.B.; CEBALLOS, H.; ROJANARIDPICHED, C.; PHUMICHAI, C. Molecular characterization of a spontaneous waxy starch mutation in cassava. Crop Science, v.52, p.2121-2130, 2012. DOI: https://doi.org/10.2135/cropsci2012.01.0058.

BERNARDO, C.O.; ASCHERI, J.L.R.; CHÁVEZ, D.W.H.; CARVALHO, C.W.P. Ultrasound assisted extraction of yam (Dioscorea bulbifera) starch: effect on morphology and functional properties. Starch/Stärke, v.70, 1700185, 2018. DOI: https://doi.org/10.1002/star.201700185.

CHARRAD, M.; GHAZZALI, N.; BOITEAU, V.; NIKNAFS, A. NbClust: an $\mathrm{R}$ package for determining the relevant number of clusters in a data set. Journal of Statistical Software, v.61, p.136, 2014. DOI: https://doi.org/10.18637/jss.v061.i06.

CLASEN, S.H.; MÜLLER, C.M.O.; PARIZE, A.L.; PIRES, A.T.N. Synthesis and characterization of cassava starch with maleic acid derivatives by etherification reaction. Carbohydrate Polymers, v.180, p.348-353, 2018. DOI: https://doi.org/10.1016/j. carbpol.2017.10.016.

COSTA, M.S.; VOLANTI, D.P.; GROSSMANN, M.V.E.; FRANCO, C.M.L. Structural, thermal, and morphological characteristics of cassava amylodextrins. Journal of the Science of Food and Agriculture, v.98, p.2751-2760, 2018. DOI: https://doi.org/10.1002/jsfa.8771.

DEL BUONO, D.; LUZI, F.; BENINCASA, P.; KENNY, J.M.; TORRE, L.; PUGLIA, D. Extraction of nanostructured starch from purified granules of waxy and non-waxy barley cultivars. Industrial Crops and Products, v.130, p.520-527, 2019. DOI: https://doi.org/10.1016/j.indcrop.2019.01.015.

DIAMANTINO, V.R.; COSTA, M.S.; TABOGA, S.R.; VILAMAIOR, P.S.L.; FRANCO, C.M.L.; PENNA, A.L.B. Starch as a potential fat replacer for application in cheese: behaviour of different starches in casein/starch mixtures and in the casein matrix. International Dairy Journal, v.89, p.129-138, 2019. DOI: https://doi.org/10.1016/j.idairyj.2018.08.015.

DRUNKLER, N.L.; LEITE, R.S.; MANDARINO, J.M.G.; IDA, E.I.; DEMIATE, I.M. Cassava starch as a stabilizer of soy-based beverages. Food Science and Technology International, v.18, p.489-499, 2012. DOI: https://doi.org/10.1177/1082013211433072.

EVERITT, B.S. Looking at multivariate data. In: EVERITT, B.S. An R and S-PLUS ${ }^{\circledR}$ companion to multivariate analysis. London: Springer, 2005. p.16-40. DOI: https://doi.org/10.1007/184628-124-5 2.

FERREIRA, F.S.; SAMPAIO, G.R.; KELLER, L.M.; SAWAYA, A.C.H.F.; CHÁVEZ, D.W.H.; TORRES, E.A.F.S.; 
SALDANHA, T. Impact of air frying on cholesterol and fatty acids oxidation in sardines: protective effects of aromatic herbs. Journal of Food Science, v.82, p.2823-2831, 2017. DOI: https://doi.org/10.1111/1750-3841.13967.

HSIEH, C.-F.; LIU, W.; WHALEY, J.K.; SHI, Y.-C. Structure, properties, and potential applications of waxy tapioca starches - a review. Trends in Food Science \& Technology, v.83, p.225-234, 2019. DOI: https://doi.org/10.1016/j.tifs.2018.11.022.

ISO. International Organization for Standardization. ISO 6647-2: Rice: determination of amylose content. Part 2: routine methods. $2^{\text {nd }} e d$. Genéve, 2015.

JANE, J.; CHEN, Y.Y.; LEE, L.F.; MCPHERSON, A.E.; WONG, K.S.; RADOSAVLJEVIC, M.; KASEMSUWAN, T. Effects of amylopectin branch chain length and amylose content on the gelatinization and pasting properties of starch. Cereal Chemistry, v.76, p.629-637, 1999. DOI: https://doi.org/10.1094/ CCHEM.1999.76.5.629.

KARLSTRÖM, A.; CALLE, F.; SALAZAR, S.; MORANTE, N.; DUFOUR, D.; CEBALLOS, H. Biological implications in cassava for the production of amylose-free starch: impact on root yield and related traits. Frontiers in Plant Science, v.7, art.604, 2016. DOI: https://doi.org/10.3389/fpls.2016.00604.

LUCHESE, C.L.; SPADA, J.C.; TESSARO, I.C. Starch content affects physicochemical properties of corn and cassava starchbased films. Industrial Crops and Products, v.109, p.619-626, 2017. DOI: https://doi.org/10.1016/j.indcrop.2017.09.020.

PARK, I.-M.; IBÁÑEZ, A.M.; ZHONG, F.; SHOEMAKER, C.F. Gelatinization and pasting properties of waxy and nonwaxy rice starches. Starch/Stärke, v.59, p.388-396, 2007. DOI: https://doi.org/10.1002/star.200600570.

R CORE TEAM. R: a language and environment for statistical computing. Vienna: R Foundation for Statistical Computing, 2016.

SÁNCHEZ, T.; DUFOUR, D.; MORENO, I.X.; CEBALLOS, H. Comparison of pasting and gel stabilities of waxy and normal starches from potato, maize, and rice with those of a novel waxy cassava starch under thermal, chemical, and mechanical stress. Journal of Agricultural and Food Chemistry, v.58, p.50935099, 2010. DOI: https://doi.org/10.1021/jf1001606.

SCHMITZ, G.J.H.; PERONI-OKITA, F.H.G.; NASCIMENTO, J.R.O. do; CAMPANHA, R.B.; VALLE, T.S.; FRANCO, C.M.L.; CORDENUNSI-LYSENKO, B.R. Selected physicochemical properties of starches isolated from ten cassava varieties reveal novel industrial uses. Starch/Stärke, v.69, 1600272, 2017. DOI: https://doi.org/10.1002/star.201600272.
SHANG, M.; CHEN, H.; WANG, Y.; LI, Q. Effect of single and dual heat-moisture treatments on the gelatinization properties and crystalline structure of normal corn starch. Starch/Stärke, v.68, p.1196-1202, 2016. DOI: https://doi.org/10.1002/star.201500350.

SHEVKANI, K.; SINGH, N.; BAJAJ, R.; KAUR, A. Wheat starch production, structure, functionality and applications - a review. International Journal of Food Science \& Technology, v.52, p.38-58, 2017. DOI: https://doi.org/10.1111/ijfs.13266.

SRICHUWONG, S.; SUNARTI, T.C.; MISHIMA, T.; ISONO, N.; HISAMATSU, M. Starches from different botanical sources I: contribution of amylopectin fine structure to thermal properties and enzyme digestibility. Carbohydrate Polymers, v.60, p.529538, 2005. DOI: https://doi.org/10.1016/j.carbpol.2005.03.004.

TEIXEIRA, B.S.; GARCIA, R.H.L.; TAKINAMI, P.Y.I.; DEL MASTRO, N.L. Comparison of gamma radiation effects on natural corn and potato starches and modified cassava starch. Radiation Physics and Chemistry, v.142, p.44-49, 2018. DOI: https://doi.org/10.1016/j.radphyschem.2017.09.001.

TELES, A.S.C.; CHÁVEZ, D.W.H.; OLIVEIRA, R.A.; BON, E.P.S.; TERZI, S.C.; SOUZA, E.F.; GOTTSCHALK, L.M.F.; TONON, R.V. Use of grape pomace for the production of hydrolytic enzymes by solid-state fermentation and recovery of its bioactive compounds. Food Research International, v.120, p.441-448, 2019. DOI: https://doi.org/10.1016/j.foodres.2018.10.083.

VELÁSQUEZ-CASTILLO, L.E.; LEITE, M.A.; DITCHFIELD, C.; SOBRAL, P.J. do A.; MORAES, I.C.F. Quinoa starch nanocrystals production by acid hydrolysis: kinetics and properties. International Journal of Biological Macromolecules, v.143, p.93101, 2020. DOI: https://doi.org/10.1016/j.ijbiomac.2019.12.011.

WANG, X.; REDDY, C.K.; XU, B. A systematic comparative study on morphological, crystallinity, pasting, thermal and functional characteristics of starches resources utilized in China. Food Chemistry, v.259, p.81-88, 2018. DOI: https://doi.org/10.1016/j.foodchem.2018.03.121.

WASSERMAN, L.A.; PAPAKHIN, A.A.; BORODINA, Z.M.; KRIVANDIN, A.V.; SERGEEV, A.I.; TARASOV, V.F. Some physico-chemical and thermodynamic characteristics of maize starches hydrolyzed by glucoamylase. Carbohydrate Polymers, v.212, p.260-269, 2019. DOI: https://doi.org/10.1016/j. carbpol.2019.01.096.

WONG, K.S.; JANE, J. Effects of pushing agents on the separation and detection of debranched amylopectin by high-performance anion-exchange chromatography with pulsed amperometric detection. Journal of Liquid Chromatography, v.18, p.63-80, 1995. DOI: https://doi.org/10.1080/10826079508009221. 